\title{
Female urethral stricture: techniques for reconstruction
}

\author{
Ignacio Alvarez de Toledo, Jessica DeLong \\ Department of Urology, Eastern Virginia Medical School, Norfolk, VA 23462, USA. \\ Correspondence to: Dr. Jessica DeLong, Department of Urology, Eastern Virginia Medical School, Urology of Virginia, 225 \\ Clearfield Avenue, Virginia Beach, VA 23462, USA. E-mail: jessicadelong@gmail.com
}

How to cite this article: de Toledo IA, DeLong J. Female urethral stricture: techniques for reconstruction. Plast Aesthet Res 2022;9:5. https://dx.doi.org/10.20517/2347-9264.2021.103

Received: 16 Sep 2021 First Decision: 25 Oct 2021 Revised: 11 Nov 2021 Accepted: 7 Dec 2021 Published: 14 Jan 2022

Academic Editors: Miroslav L. Djorjdjevic, Stan Monstrey Copy Editor: Xi-Jun Chen Production Editor: Xi-Jun Chen

\begin{abstract}
Female urethral stricture (FUS) is a rare condition. It was not studied robustly for many years, but interest has grown recently in the reconstructive urology community, leading to an increase in publications. In this review, we gather the latest data regarding FUS and its different therapeutic options. Studies are summarized, split by technique. We also review the recently published European Guidelines. In addition, we share our preferred surgical technique and our views on future options. Diagnosing FUS can often be challenging and requires a high index of clinical suspicion. Its vague clinical symptoms and empiric initial treatments combine to make FUS an underdiagnosed condition. The lack of consensus on how to define FUS also compounds the problem. Appropriate diagnosis requires thorough investigation, and ancillary studies such as video urodynamics, cystoscopy, and voiding cystourethrogram may be useful. Treatment options range from conservative management to definitive procedures, although studies have shown that conservative measures such as urethral dilation have a low success rate overall. Within definitive management, augmented urethroplasty - using either flaps or grafts, has proven to be the gold standard. Both have shown excellent results over time; however, there is insufficient data available to recommend one over the other. Contemporary data has an overall poor level of evidence. Although challenging due to the rarity of the problem, a proper randomized controlled clinical trial comparing the principal surgical options and their outcomes would be beneficial and would allow for more informed decision making when considering options for women with urethral stricture.
\end{abstract}


Keywords: Urethra, female urethral stricture, female urethroplasty, buccal mucosal graft, vaginal flap

\section{INTRODUCTION}

Bladder outlet obstruction (BOO) in women remains a challenging scenario. Care needs to be taken not to confuse functional entities with anatomic to offer appropriate care to the patient. By far, more women with obstructive symptoms will have a functional etiology. Within anatomic etiologies, female urethral stricture (FUS) disease accounts for a considerable proportion ranging from $4 \%$ to $18 \%$ of women with $\mathrm{BOO}^{[1]}$. However, there is a generalized consensus that FUS is likely underdiagnosed due to the lack of wellestablished diagnostic criteria and relatively nonspecific symptoms. Some studies report a higher incidence of up to $8 \%-22.4 \%$ in women with obstructive symptoms ${ }^{[2]}$. There is no single definition of FUS that exists, nor an accepted descriptive nomogram. Some authors propose that a urethral lumen too narrow to admit a $17 \mathrm{Fr}$ flexible cystoscope or that has the feel of scar tissue by cystoscopic haptic feedback is diagnostic for stricture $^{[1]}$. In contrast, others opine that FUS should be defined as a fixed anatomical narrowing of the urethra such that the lumen will not accommodate instrumentation without disruption of the urethral mucosal lining ${ }^{[3]}$. Uroflow can be helpful in trying to diagnose a FUS, although there is no consensus regarding its cut-off values.

FUS somewhat mimics their male counterparts regarding etiology, with notable differences regarding traumatic etiology. Almost every stricture can be attributed to 4 etiologies (in order of most to least frequent): idiopathic, iatrogenic, inflammatory, or traumatic ${ }^{[4]}$. There is a small proportion of rare etiologies, which include: urethral tuberculosis, urethral carcinoma, locally advanced cervical carcinoma, fibroepithelial polyps and infection ${ }^{[5-7]}$. Within iatrogenic etiologies, the most common are: prior urethral dilations, prior urethral diverticulectomy, sling insertion or excision, transvaginal fistula repair and/or transurethral bladder surgery.

Evidence is overall poor for female urethral stricture management, and included here is a contemporary literature review and a summary of the recently published European Guidelines ${ }^{[8]}$. In this article, we will also review our recommended workup and management of FUS, with a focus on options for surgical treatment.

\section{DIAGNOSIS AND EVALUATION}

The diagnosis of FUS requires a high index of clinical suspicion. A thorough investigation is essential for diagnosis, to plan appropriate treatment, and to exclude differential diagnoses such as functional BOO, urethral diverticulum or malignancy. It is very important to collect sufficient data regarding past medical history, prior procedures, history of pelvic malignancies, radiation, etc. As mentioned above, FUS is often underdiagnosed, and the lack of standardization about the diagnosis of $\mathrm{BOO}$ in women emphasizes that $\mathrm{BOO}$ is often a clinical diagnosis $\mathrm{s}^{[9]}$. An adequate physical exam is also mandatory as it will give important information about tissue quality, meatal stenosis, pelvic organ prolapse and/or concomitant lichen sclerosus (LS). Faiena et al. ${ }^{[10]}$ state that physical examination with bimanual pelvic, vaginal and speculum examinations are essential.

Patients with FUS have variable lower urinary tract symptoms (LUTS). As Kuo ${ }^{[11]}$ demonstrated, the differential diagnosis of lower urinary tract dysfunction in women cannot be based on LUTS alone. Patients with urethral stricture may be asymptomatic or present a variety of symptoms ranging from minor discomfort to a wide spectrum of voiding and storage symptoms. 
Initial workup should include uroflow and post-void residual (PVR). While there are no specific cutoffs for uroflowmetry or PVR volumes, a curve that reaches a plateau, flow less than 12 to $15 \mathrm{~mL} / \mathrm{s}$, or PVRs > 100, may suggest obstruction ${ }^{[12]}$. Cystourethroscopy can be useful, although a smaller diameter pediatric scope may be necessary. This can yield information about the stricture itself, bladder health, and any concomitant pathology. Urethral calibration with bougie-à-boule can be very helpful in understanding the caliber of the stricture and having an objective measurement prior to undergoing surgical management, although Kalra et al. ${ }^{[13]}$ found that we should not rely on urethral calibration only given that a good caliber of the urethra (14 Fr) is not sufficient enough to rule out a significant obstruction due to FUS.

Unlike male patients, retrograde urethrography and voiding cystourethrography (VCUG) do not play a central role in the diagnosis and evaluation of FUS. It can often be challenging to distinguish between a primary bladder neck obstruction, a urethral sphincter obstruction, a pelvic floor obstruction, or a urethral stricture itself. If done, we recommend positioning the patient in an A-P fashion and relying more heavily on the voiding film. Urethrography can help determine the position of the stricture within the urethra (proximal, mid, distal, or panurethral).

Finally, a urodynamic study (UDS) will show a classic high pressure low flow pattern. Although there is no consensus regarding cut-off values for FUS, West et al. ${ }^{[14]}$ suggest that detrusor contraction at a maximum of $>25 \mathrm{~cm} \mathrm{H} \mathrm{H}_{2} \mathrm{O}$, with a flow $<12 \mathrm{cc} / \mathrm{s}$, could be diagnostic of BOO, and the nomogram proposed by Blaivas and Grout ${ }^{[15]}$ may be utilized to confirm obstruction. It is recommended to add fluoroscopy and do a video-UDS to maximize the data a UDS offers. Since female detrusor pressure values are highly variable, it was not until urodynamic data was fused with fluoroscopic imaging that conclusions could be drawn on functional and anatomic criteria ${ }^{[16]}$. A pelvic MRI may be helpful in some cases, particularly if there is suspicion of pelvic organ prolapse or additional pathology such as malignancy. Sarin et al. ${ }^{[4]}$ summarize that calibration of < $14 \mathrm{~F}$ (most commonly used cut-off value by authors), evidence of BOO on urodynamics, and visualization of narrowing on urethroscopy or VCUG may be diagnostic of FUS.

\section{SURGICAL TECHNIQUE}

\section{Conservative management}

Minimally invasive treatment for FUS remains the most popular among urologists. Both urethral dilation (UD) and direct vision internal urethrotomy are the available conservative options. According to a 2006 British Survey, $69 \%$ of urologists were still regularly practicing $U D^{[17]}$; these practice patterns may have changed over the past 15 years favoring surgical intervention. Furthermore, a majority of urologists believe that the first intervention for female urethral stricture should be urethral dilatation ${ }^{[18]}$, a treatment option supported by recent guidelines ${ }^{[8]}$.

Although easy to do and relatively low risk, judicious use of UD is advised. Santucci et al. ${ }^{[19]}$ reported that only 40 patients out of a population of 1.2 million with urethral stricture had undergone reconstructive surgery. This not only resulted in deterioration of patients' health and quality of life but also resulted in increased health costs with $\$ 61$ million/year spent on female urethral dilation.

Data are limited to retrospective series, small patient populations without adequate long-term follow-up. UD overall success is noted to be between $47 \%-49 \%{ }^{[4,20]}$, with success defined as the lack of need for further intervention. These numbers parallel what is seen in male patients as well regarding endoscopic management of urethral strictures. Mean time to failure with UD was 12 month $^{[21]}$. In our practice, we follow the same principle as in male patients with no more than one attempt of UD per patient given the poor outcomes of repeated dilations $(30 \%)$, unless the patient is not a surgical candidate ${ }^{[22]}$. Spilotros et al. ${ }^{[23]}$ 
reported a low success rate with one UD procedure, and half of those patients required an additional dilation. Some authors reported a $67 \%-68 \%$ success rate with UD, but this may be attributed to a shorter follow-up period ${ }^{[24,25]}$.

With the increasing interest in this uncommon problem, there has begun a paradigm shift that reflects different training, and more surgeons are choosing to abandon the practice of serial dilations in favor of performing definitive reconstructive repairs. Table 1 summarizes available original articles with outcomes for women undergoing urethral dilation for urethral stricture over the last ten years. The mean success rate in these studies was $54.4 \%$ at a mean follow-up of 34.1 months ${ }^{[21-25]}$.

\section{Definitive management}

It is important to distinguish between conservative vs. definitive treatment for FUS. As discussed earlier, serial urethral dilation is an acceptable option for managing symptoms, but its high failure rate makes it a substandard choice when considering definitive treatment. Furthermore, since there has been a growing interest in the management of this rare pathology, some reconstructive urologists suggest that primary urethroplasty can be considered a first-line option for FUS treatment ${ }^{[26]}$.

The goals for female urethral reconstruction are to restore function, urinate without obstruction, maintain continence, prevent vaginal voiding, and maintain sexual function. Although these goals are considered an ideal scenario, there is a dearth of literature considering all five variables when analyzing outcomes. Alternatives when considering a surgical approach are an augmented urethroplasty with a flap or graft $v s$. a non-augmented urethroplasty: excision and primary anastomosis (EPA) or meatoplasty. The choice is based upon stricture characteristics and surgeon preference as there is insufficient evidence to support one technique over another, which is reflected in the European Guidelines ${ }^{[8]}$.

Reports on EPA in female urethral strictures are few. However, it may be recommended in strictures due to pelvic fracture and under a sine qua non condition that stricture is short and in the proximal or mid urethra. In addition, there are reports of robotic-assisted techniques being utilized for patients with proximal short traumatic stricture.

In cases where there is an isolated distal urethral stricture, meatoplasty should be considered. This usually occurs after traumatic instrumentation, radiation therapy to the pelvis, and more commonly in postmenopausal patients with vulvar and vaginal atrophy. Care needs to be taken not to make the incision too ventral to prevent vaginal voiding. Rosenblum et al. ${ }^{[27]}$ suggest that circumferential, distal urethrectomy and advancement meatoplasty work best for treating these distal strictures. This is also the preferred technique of the authors.

\section{Flaps}

The utilization of tissue flaps for reconstruction is one of the oldest tools available for reconstructive surgery, and it remains a valid option when considering approaches for urethroplasty in women. Various authors have published their results using vaginal flaps, with a success rate that ranges between $60 \%-100 \%$ according to our literature review ${ }^{[2,24-26,28-31]}$ [Table 2]. However, there is wide variation, likely due to several factors, including a range of follow-up (12 to 72 months), varied etiology, and surgical technique.

Flaps can be obtained from vaginal (U-shaped or C-shaped), labial, or vestibular tissue, and their versatility allows them to be placed either in a ventral position (vaginal, labial tissue) or dorsally (vestibular tissue). The anterior vaginal wall flap and lateral vaginal wall flap techniques have proven safety and efficacy, 
Table 1. Outcomes of women undergoing dilation for urethral stricture

\begin{tabular}{|c|c|c|c|c|c|c|c|c|c|}
\hline Authors & Year & $\begin{array}{l}\text { Study } \\
\text { type }\end{array}$ & $n$ & $\begin{array}{l}\text { Mean age } \\
\text { (years) }\end{array}$ & $\begin{array}{l}\text { Concomitant } \\
\text { procedure }\end{array}$ & $\begin{array}{l}\text { Postop. } \\
\text { SUI }\end{array}$ & $\begin{array}{l}\text { Success } \\
(\%)\end{array}$ & $\begin{array}{l}\text { Follow-up } \\
\text { (months) }\end{array}$ & Complications \\
\hline Romman et al. $^{[21]}$ & 2015 & $\begin{array}{l}\text { Original } \\
\text { Article }\end{array}$ & 93 & 51 & No & No & 51 & 46 & No \\
\hline $\begin{array}{l}\text { Popat and } \\
\text { Zimmern }^{[22]}\end{array}$ & 2016 & $\begin{array}{l}\text { Original } \\
\text { Article }\end{array}$ & 30 & 55 & No & No & 43 & 59 & No \\
\hline Spilotros et al. ${ }^{[23]}$ & 2017 & $\begin{array}{l}\text { Original } \\
\text { Article }\end{array}$ & 8 & 45 & No & No & 0 & 35 & No \\
\hline Tao et al. ${ }^{[24]}$ & 2018 & $\begin{array}{l}\text { Original } \\
\text { Article }\end{array}$ & 9 & 54 & No & No & 67 & 12 & No \\
\hline Lane et al. ${ }^{[25]}$ & 2020 & $\begin{array}{l}\text { Original } \\
\text { Article }\end{array}$ & 75 & 56 & No & No & 68 & 12 & No \\
\hline Summary & & & 215 & 53.2 & & & 54.5 & 34.1 & \\
\hline
\end{tabular}

SUI: Stress urinary incontinence.

Table 2. Outcomes of women undergoing flap urethroplasty for urethral stricture

\begin{tabular}{|c|c|c|c|c|c|c|c|c|c|}
\hline Authors & Year & $\begin{array}{l}\text { Study } \\
\text { type }\end{array}$ & $n$ & $\begin{array}{l}\text { Mean age } \\
\text { (years) }\end{array}$ & $\begin{array}{l}\text { Concomitant } \\
\text { procedure }\end{array}$ & $\begin{array}{l}\text { Postop. } \\
\text { SUI }\end{array}$ & $\begin{array}{l}\text { Success } \\
(\%)\end{array}$ & $\begin{array}{l}\text { Follow-up } \\
\text { (months) }\end{array}$ & Complications \\
\hline Simonato et al. ${ }^{[29]}$ & 2010 & $\begin{array}{l}\text { Original } \\
\text { Article }\end{array}$ & 6 & 67 & No & No & 100 & 70 & No \\
\hline Önol et al. ${ }^{[26]}$ & 2011 & $\begin{array}{l}\text { Original } \\
\text { Article }\end{array}$ & 10 & 46 & No & No & 100 & 36 & No \\
\hline Kowalik et al. ${ }^{[30]}$ & 2014 & $\begin{array}{l}\text { Original } \\
\text { Article }\end{array}$ & 5 & 49 & $\begin{array}{l}\text { Yes (sling \& } \\
\text { nephrectomy) }\end{array}$ & No & 60 & 47 & No \\
\hline Romman et al. ${ }^{[21]}$ & 2015 & $\begin{array}{l}\text { Original } \\
\text { Article }\end{array}$ & 28 & 51 & No & No & 68 & 52 & No \\
\hline Romero-Maroto et al. ${ }^{[28]}$ & 2016 & $\begin{array}{l}\text { Original } \\
\text { Article }\end{array}$ & 9 & 56 & No & No & 89 & 80 & No \\
\hline Tao et al. ${ }^{[24]}$ & 2018 & $\begin{array}{l}\text { Original } \\
\text { Article }\end{array}$ & 12 & 54 & No & No & 100 & 12 & No \\
\hline Hajebrahimi et al. ${ }^{[31]}$ & 2019 & $\begin{array}{l}\text { Original } \\
\text { Article }\end{array}$ & 14 & 54 & No & Yes & 100 & 16 & UUI \& SUI \\
\hline Lane et al. ${ }^{[25]}$ & 2020 & $\begin{array}{l}\text { Original } \\
\text { Article }\end{array}$ & 68 & 56 & Yes (15\%) & Yes & 83 & 12 & Yes (15\%) \\
\hline Summary & & & 152 & 54.2 & & & 84.5 & 28.7 & \\
\hline
\end{tabular}

SUI: Stress urinary incontinence; UUI: urge urinary incontinence.

although some authors suggest that the latter is superior since it does not result in a retrusive meatus and an inward urinary stream ${ }^{[28]}$. On the contrary, Simonato et al. ${ }^{[29]}$ reported no complications with the lateral flap technique.

The advantages of using local flaps rely on their robust vascularity and adequate mobility characteristics along with relatively low morbidity. Acceptable complication rates were reported with these procedures, with only $3.7 \%$ de novo stress urinary incontinence (SUI) noted ${ }^{[4]}$. Furthermore, in patients with concomitant SUI, a pubovaginal sling could be placed without major impediments ${ }^{[25,30]}$. In one series, a sling was necessary due to persistent SUI 12 months after surgery ${ }^{[31]}$.

Some authors opine that patients who required intermittent self-catheterization for a short period after urethroplasty should not be considered a failure ${ }^{[32]}$. In addition, it is debatable whether estrogen status may affect local tissue use. Finally, an important limitation of flap utilization is local tissue health. Flaps should 
not be used for patients with lichen sclerosus or other conditions such as radiation that result in unhealthy tissue.

\section{Grafts}

Graft augmentation urethroplasty has gained popularity, both in male and female patients. Free grafts may be obtained from local tissue (vaginal, labial) and oral mucosa (buccal, lingual). Tables 3 and 4 compile the past 10-year-period study outcomes of local and oral grafts, respectively ${ }^{[2,23,25,26,30,33-44]}$. Vaginal or labial graft augmentation had an $80 \%-87 \%$ mean success rate, whereas oral mucosa grafts' mean success rate ranged between $89 \%-94 \%^{[4,20]}$. With an average follow-up of over 18 months, mean success closely matches that of patients who underwent flap urethroplasty.

Using local tissue to harvest graft is not advised in patients with LS. Also, care needs to be taken when considering estrogen-sensitive local grafts in post-menopausal patients. Hormone creams may be helpful when using local grafts in these women, as suggested by Romero-Maroto et al. ${ }^{[28]}$. Some authors advocate the use of labia minora grafts ${ }^{[3,34]}$, whereas others prefer harvesting a vaginal mucosa graft ${ }^{[35,36]}$. Data reflects that both techniques have proven to be equally efficacious with similar surgical outcomes.

On the other hand, buccal mucosa grafts have gained popularity, at least in part because of their versatility. These are easy to harvest, with low donor site morbidity. They are easy to handle, have good graft take, and minimal contracture; these unique characteristics make them an ideal substitute tissue for urethroplasties. Sharma et al. ${ }^{[37]}$ presented their work using lingual mucosa grafts with acceptable results compared to the available literature. In our experience, we only use lingual mucosa grafts when we have no available healthy buccal mucosa to harvest.

Where to place the graft remains a subject of controversy. There exists a debate regarding a dorsal $v s$. a ventral approach. The decision to place a ventral graft relies on the presumption that it is an easier dissection and that it would preserve sexual function, although there is one study that showed that sexual function is not affected with dorsal approach and, even more, it documented an improvement in sexual function scores ${ }^{[38]}$. In their respective series, none of the authors performing a dorsal approach reported a decrease in sexual function ${ }^{[39-41]}$. A dorsal approach preserves ventral tissue planes in case there is a need for a future continence procedure. Additionally, Gomez and Pfeifer ${ }^{[45]}$ proposed the idea that the dorsal approach may entail a lesser risk of incontinence by preserving ventro-lateral supporting structures. Similar de novo SUI rates were found in both approaches (3.6\% with a dorsal approach $v s .5 .8 \%$ with a ventral approach) in a review by Sarin et al..$^{[4]}$. Although it has been suggested that the ventral approach might increase the risk of urethro-vaginal fistula, there is no data available regarding this complication. Coguplugil et al. ${ }^{[43]}$ suggest that performing a full-thickness vaginal dissection might prevent fistula formation.

\section{OUR TECHNIQUE}

We favor the dorsal onlay buccal mucosal graft, although some might argue it is a more difficult approach. The risk of sexual dysfunction with this dissection is low, as the plane of dissection is well away from neurovascular clitoral structures. As stated above, leaving the ventral plane untouched might be convenient for a possible continence procedure in the future if needed. In addition, it helps prevent sacculation of the graft. We harvest, clean, and fenestrate a $4 \mathrm{~cm} \times 2 \mathrm{~cm}$ buccal mucosal graft in the standard fashion. Typically given the length of the female urethra, a longer graft is not required even in situations where the stricture is panurethral. A semilunar, suprameatal incision is made. Careful dissection is carried outside the corpus spongiosum until a healthy urethra is encountered. We typically open the meatus; however, a 
Table 3. Outcomes of women undergoing local graft urethroplasty for urethral stricture

\begin{tabular}{|c|c|c|c|c|c|c|c|c|c|}
\hline Authors & Year & $\begin{array}{l}\text { Study } \\
\text { type }\end{array}$ & $n$ & $\begin{array}{l}\text { Mean age } \\
\text { (years) }\end{array}$ & $\begin{array}{l}\text { Concomitant } \\
\text { procedure }\end{array}$ & $\begin{array}{l}\text { Postop. } \\
\text { SUI }\end{array}$ & $\begin{array}{l}\text { Success } \\
(\%)\end{array}$ & $\begin{array}{l}\text { Follow-up } \\
\text { (months) }\end{array}$ & Complications \\
\hline Rehder et al. $^{[33]}$ & 2010 & $\begin{array}{l}\text { Original } \\
\text { Article }\end{array}$ & 8 & 45 & No & No & $75 \%$ & 22 & No \\
\hline Gozzi et al..$^{[34]}$ & 2011 & $\begin{array}{l}\text { Original } \\
\text { Article }\end{array}$ & 4 & 58 & No & No & $100 \%$ & 15 & No \\
\hline Önol et al. ${ }^{[26]}$ & 2011 & $\begin{array}{l}\text { Original } \\
\text { Article }\end{array}$ & 7 & 46 & No & No & $86 \%$ & 18 & No \\
\hline Petrou et al. ${ }^{[35]}$ & 2012 & $\begin{array}{l}\text { Original } \\
\text { Article }\end{array}$ & 11 & 60 & No & No & $73 \%$ & 23 & No \\
\hline Singh et al. ${ }^{[36]}$ & 2013 & $\begin{array}{l}\text { Original } \\
\text { Article }\end{array}$ & 16 & 47 & No & No & $94 \%$ & 24 & $\begin{array}{l}\text { ISC weekly at } 3 \\
\text { months }\end{array}$ \\
\hline Manasa et al..$^{[38]}$ & 2019 & $\begin{array}{l}\text { Original } \\
\text { Article }\end{array}$ & 13 & 43 & No & No & $77 \%$ & 8 & No \\
\hline Summary & - & - & 59 & 48.8 & - & - & $83.2 \%$ & 18.6 & - \\
\hline
\end{tabular}

SUI: Stress urinary incontinence; ISC: intermittent self calibration.

Table 4. Outcomes of women undergoing oral graft urethroplasty for urethral stricture

\begin{tabular}{|c|c|c|c|c|c|c|c|c|c|}
\hline Authors & Year & $\begin{array}{l}\text { Study } \\
\text { type }\end{array}$ & $n$ & $\begin{array}{l}\text { Mean age } \\
\text { (years) }\end{array}$ & $\begin{array}{l}\text { Concomitant } \\
\text { procedure }\end{array}$ & $\begin{array}{l}\text { Postop. } \\
\text { SUI }\end{array}$ & $\begin{array}{l}\text { Success } \\
(\%)\end{array}$ & $\begin{array}{l}\text { Follow-up } \\
\text { (months) }\end{array}$ & Complications \\
\hline Sharma et al. ${ }^{[37]}$ & 2010 & $\begin{array}{l}\text { Original } \\
\text { Article }\end{array}$ & 5 & 42 & No & No & 93 & 12 & Wound infection \\
\hline Önol et al. ${ }^{[26]}$ & 2011 & $\begin{array}{l}\text { Original } \\
\text { Article }\end{array}$ & 6 & 46 & Martius flap & No & 100 & 17 & No \\
\hline Kowalik et al. ${ }^{[30]}$ & 2014 & $\begin{array}{l}\text { Original } \\
\text { Article }\end{array}$ & 4 & 49 & No & No & 100 & 24 & No \\
\hline Goel et al. ${ }^{[39]}$ & 2013 & $\begin{array}{l}\text { Original } \\
\text { Article }\end{array}$ & 8 & 40 & No & No & 63 & 14 & No \\
\hline Spilotros et al. ${ }^{[23]}$ & 2017 & $\begin{array}{l}\text { Original } \\
\text { Article }\end{array}$ & 14 & 45 & Martius Flap & No & 93 & 12 & No \\
\hline Mukhtar et al. ${ }^{[2]}$ & 2017 & $\begin{array}{l}\text { Original } \\
\text { Article }\end{array}$ & 22 & 50 & Martius Flap & No & 96 & 21 & $\begin{array}{l}\text { Urethral } \\
\text { diverticulum (2) }\end{array}$ \\
\hline Powell and Daniels ${ }^{[40]}$ & 2017 & $\begin{array}{l}\text { Original } \\
\text { Article }\end{array}$ & 6 & 52 & No & No & 67 & 18 & $\begin{array}{l}\text { Donor site } \\
\text { bleeding (2) }\end{array}$ \\
\hline Hampson et al. ${ }^{[44]}$ & 2019 & $\begin{array}{l}\text { Original } \\
\text { Article }\end{array}$ & 39 & 50 & $\begin{array}{l}\text { Anti-incontinent } \\
\text { procedure (1) }\end{array}$ & No & 77 & 33 & UTI (7) \\
\hline Nayak et al. ${ }^{[42]}$ & 2019 & $\begin{array}{l}\text { Original } \\
\text { Article }\end{array}$ & 12 & 41 & No & No & 92 & 18 & No \\
\hline Lane et al. ${ }^{[25]}$ & 2020 & $\begin{array}{l}\text { Original } \\
\text { Article }\end{array}$ & 67 & 55 & Yes (6\%) & Yes & 77 & 12 & Yes $(18 \%)$ \\
\hline Coguplugil et al..$^{[43]}$ & 2021 & $\begin{array}{l}\text { Original } \\
\text { Article }\end{array}$ & 8 & 50 & No & No & 100 & 16 & Dyspareunia (1) \\
\hline Khawaja et al. ${ }^{[41]}$ & 2021 & $\begin{array}{l}\text { Original } \\
\text { Article }\end{array}$ & 25 & 46 & No & No & 92 & 25 & No \\
\hline Summary & - & - & 226 & 49.2 & - & - & 84.4 & 18.9 & - \\
\hline
\end{tabular}

SUI: Stress urinary incontinence; UTI: urinary tract infection.

meatus-sparing technique is also acceptable. The dissection may be carried out to the bladder neck when indicated without fear of de novo stress urinary incontinence. The graft is sewn in with delayed absorbable suture; we favor 4-0 PDS. Several quilting sutures of 5-0 Vicryl are placed. We ensure patency to 30 Fr with intraoperative bougie-à-boule. A 14 french silicone catheter is left in place for three weeks [Figure 1]. 

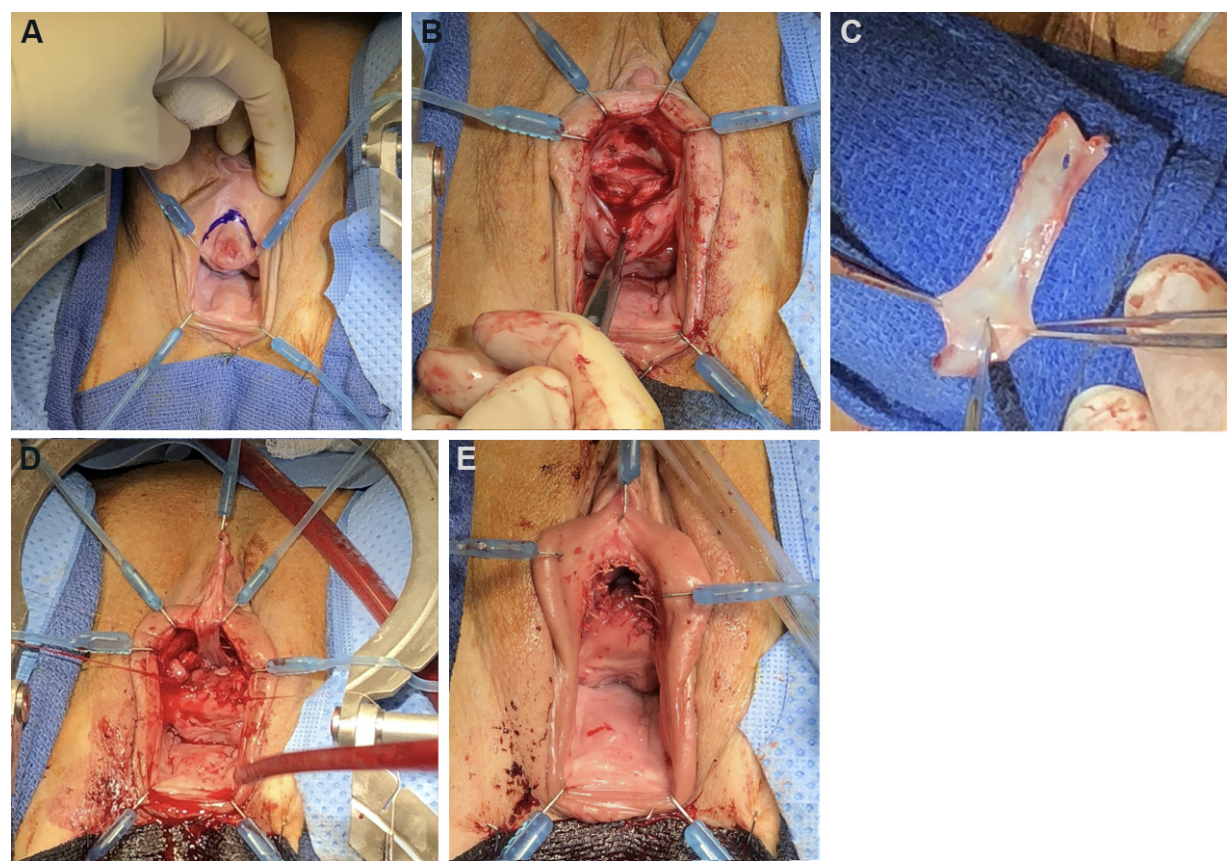

Figure 1. Dorsal onlay buccal graft urethroplasty. (A) Semilunar suprameatal incision; (B) dorsal dissection; (C) $4 \mathrm{~cm} \times 2 \mathrm{~cm}$ buccal graft; (D) apical fixation of graft; (E) neomeatus matured. Photos courtesy of Dr. DeLong.

\section{Special situations}

Within the iatrogenic causes of FUS, extra care needs to be taken with patients who have undergone pelvic radiation. As in their male counterparts, urethral strictures caused by radiation are often more complex to diagnose and treat. These patients may benefit from urodynamic evaluation to better elucidate symptoms when appropriate. There is little data regarding radiated FUS because most authors exclude them from their series. Gomez et al. ${ }^{[46]}$ report that both of their radiated patients undergoing urethroplasty failed and suggest maximizing a conservative approach with these patients. If local tissue is of poor quality, a Martius flap may be utilized to provide a healthy graft bed.

Patients with urethral stricture and concomitant stress urinary incontinence are rare. In these cases, we advocate performing a continence procedure at the same time as the urethroplasty, or at interval if preferred. In our practice, we treat the stricture with a dorsal buccal mucosa graft urethroplasty, and the stress urinary incontinence with a pubovaginal sling. Martius flap may be utilized if needed.

Some authors suggest that interposition of a Martius flap should be done in all cases when performing a ventral onlay buccal mucosa graft urethroplasty because it provides a healthy vascular base for the graft, prevents urethrovaginal fistula development and provides healthy tissue between the reconstructed urethra and the overlying vagina to facilitate any future surgery for subsequent $\mathrm{SUI}^{[2]}$.

Suprapubic tube placement pre, intra or postoperatively can be considered. In some cases, such as obliterative strictures, particularly in radiated patients, antegrade access is helpful. If the stricture is obliterative, kissing grafts (dorsal and ventral) may be utilized. Lane et al. ${ }^{[25]}$ reported that $14 \%$ of patients undergoing augment urethroplasty required a suprapubic tube placement preoperatively, and $14 \%$ of patients intraoperatively. In rare cases, a suprapubic tube placement or formal urinary diversion should be considered the definitive treatment if reconstructive alternatives fail ${ }^{[8]}$. 


\section{Future directions}

Although there have been some important advances in the understanding and management of FUS, there is still room for improvement. Data available is scarce and with an overall poor level of evidence. Published studies consist mostly of descriptive, retrospective series or technique papers with a small number of patients. Most of these are single-center with the exception of two multicenter studies ${ }^{[25,44]}$. There is a need for long-term randomized, controlled trials comparing different treatments. We also advocate the idea of the creation of an international registry to collect data prospectively for more robust and long-term evidence suggested by Chakraborty et al. ${ }^{[32]}$. The recent publication of the European Association of Urology guidelines for the management of female urethral strictures provides a framework for decision making in these cases $^{[8]}$.

In the future, new technology might play a role in managing FUS disease. Both tissue engineering and drugcoated balloons may be options that will increase our armamentarium. Although more robust data in tissue engineering is found for male patients, there are some ongoing preclinical and clinical studies open on FUS, which hopefully will show good preliminary results in this innovative field ${ }^{[47]}$. Drug-coated balloons for the treatment of urethral stricture also showed promising results in male patients with 70\% success at 12-month follow-up and is yet to be determined with future studies if it could demonstrate similar efficacy in female patients $^{[48]}$.

\section{CONCLUSION}

For many years, FUS disease has been a mostly anecdotal field. However, we have seen an increasing interest in the reconstructive urology community. Although rare, the true incidence of FUS is probably underestimated. Its vague presenting symptoms make it mandatory to have a high index of clinical suspicion to diagnose and treat the patient appropriately. A thorough clinical history is advised with emphasis on prior surgical or radiation history. In institutions without expertise in this area, referral to an experienced center is recommended. As a first-line treatment, the patient can be offered UD, but we discourage serial dilations in case of initial failure in patients who are surgical candidates. Augmentation urethroplasty, using either flaps or grafts, is the gold standard treatment in FUS. Unfortunately, there is insufficient high-quality data to recommend one approach or technique over the other. Current literature suggests acceptable success with low complication rates for flaps and grafts, independent of a specific approach. Since the available literature consists mainly of retrospective cases with a small number of patients, long-term randomized controlled trials comparing different treatment outcomes would be helpful to improve the available level of evidence. Finally, the promising field of tissue engineering may play a role in female urethroplasty, given promising preliminary results. If implemented, tissue-engineered grafts could shorten operative time and diminish donor site morbidity.

\section{DECLARATIONS}

\section{Authors' contributions}

Contributed equally to this work in writing and proofing: de Toledo IA, DeLong J

Performed the literature search: de Toledo IA

Edited the manuscript: DeLong J

Availability of data and materials

Not applicable.

\section{Financial support and sponsorship}

None. 


\section{Conflicts of interest}

Dr. DeLong is a consultant for Urotronic, Inc., and Urovant. All authors declared that there are no conflicts of interest.

\section{Ethical approval and consent to participate}

Not applicable.

\section{Consent for publication}

The photos are covered under our patient consent for video and photos signed at the time of surgery. The study obtained the consent of patients.

\section{Copyright}

(C) The Author(s) 2022.

\section{REFERENCES}

1. Blaivas JG, Santos JA, Tsui JF, et al. Management of urethral stricture in women. J Urol 2012;188:1778-82. DOI PubMed

2. Mukhtar BMB, Spilotros M, Malde S, Greenwell TJ. Ventral-onlay buccal mucosa graft substitution urethroplasty for urethral stricture in women. BJU Int 2017;120:710-6. DOI PubMed

3. Smith AL, Ferlise VJ, Rovner ES. Female urethral strictures: successful management with long-term clean intermittent catheterization after urethral dilatation. BJU Int 2006;98:96-9. DOI PubMed

4. Sarin I, Narain TA, Panwar VK, Bhadoria AS, Goldman HB, Mittal A. Deciphering the enigma of female urethral strictures: a systematic review and meta-analysis of management modalities. Neurourol Urodyn 2021;40:65-79. DOI PubMed

5. Keegan KA, Nanigian DK, Stone AR. Female urethral stricture disease. Curr Urol Rep 2008;9:419-23. DOI PubMed

6. Desai S, Libertino JA, Zinman L. Primary carcinoma of the female urethra. J Urol 1973;110:693-5. DOI PubMed

7. Indudhara R, Vaidyanathan S, Radotra BD. Urethral tuberculosis. Urol Int 1992;48:436-8. DOI PubMed

8. Riechardt S, Waterloos M, Lumen N, et al. European Association of Urology Guidelines on urethral stricture disease part 3: management of strictures in females and transgender patients. Eur Urol Focus 2021. DOI PubMed

9. McCrery RJ, Appell RA. Bladder outlet obstruction in women: iatrogenic, anatomic, and neurogenic. Curr Urol Rep 2006;7:363-9. DOI PubMed

10. Faiena I, Koprowski C, Tunuguntla H. Female urethral reconstruction. J Urol 2016;195:557-67. DOI PubMed

11. Kuo HC. Clinical symptoms are not reliable in the diagnosis of lower urinary tract dysfunction in women. J Formos Med Assoc 2012;111:386-91. DOI PubMed

12. Agochukwu-Mmonu N, Srirangapatanam S, Cohen A, Breyer B. Female urethral strictures: review of diagnosis, etiology, and management. Curr Urol Rep 2019;20:74. DOI PubMed

13. Kalra S, Gupta P, Dorairajan LN, Ramanitharan M, Sreenivasan SK, Hota S. Does successful urethral calibration rule out significant female urethral stenosis? Int Braz J Urol 2021;47:829-40. DOI PubMed PMC

14. West C, Lawrence A. Female urethroplasty: contemporary thinking. World J Urol 2019;37:619-29. DOI PubMed

15. Blaivas JG, Groutz A. Bladder outlet obstruction nomogram for women with lower urinary tract symptomatology. Neurourol Urodyn 2000;19:553-64. DOI PubMed

16. Nitti VW, Tu LM, Gitlin J. Diagnosing bladder outlet obstruction in women. J Urol 1999;161:1535-40. PubMed

17. Masarani M, Willis RG. Urethral dilatation in women: urologists' practice patterns in the UK. Ann R Coll Surg Engl 2006;88:496-8. DOI PubMed PMC

18. Heidari F, Abbaszadeh S, Ghadian A, Tehrani Kia F. On demand urethral dilatation versus intermittent urethral dilatation: results and complications in women with urethral stricture. Nephrourol Mon 2014;6:e15212. DOI PubMed PMC

19. Santucci RA, Payne CK, Anger JT, Saigal CS; Urologic Diseases in America Project. Office dilation of the female urethra: a quality of care problem in the field of urology. J Urol 2008;180:2068-75. DOI PubMed PMC

20. Osman NI, Mangera A, Chapple CR. A systematic review of surgical techniques used in the treatment of female urethral stricture. Eur Urol 2013;64:965-73. DOI PubMed

21. Romman AN, Alhalabi F, Zimmern PE. Distal intramural urethral pathology in women. J Urol 2012;188:1218-23. DOI PubMed

22. Popat S, Zimmern PE. Long-term management of luminal urethral stricture in women. Int Urogynecol J 2016;27:1735-41. DOI PubMed

23. Spilotros M, Malde S, Solomon E, et al. Female urethral stricture: a contemporary series. World J Urol 2017;35:991-5. DOI PubMed

24. Tao TT, Xu QK, Hu Q, et al. Novel surgical technique for female distal urethral stricture disease: an evaluation of efficacy and safety compared with urethral dilatation. Int J Clin Exp Med 2018;11:12002-07. DOI

25. Lane GI, Smith AL, Stambakio H, et al; Society of Urodynamics, Female Pelvic Medicine and Urogenital Reconstruction Research Network (SURN). Treatment of urethral stricture disease in women: a multi-institutional collaborative project from the SUFU research network. Neurourol Urodyn 2020;39:2433-41. DOI PubMed 
26. Önol FF, Antar B, Köse O, Erdem MR, Önol ŞY. Techniques and results of urethroplasty for female urethral strictures: our experience with 17 patients. Urology 2011;77:1318-24. DOI PubMed

27. Rosenblum N, Nitti VW. Female urethral reconstruction. Urol Clin North Am 2011;38:55-64, vi. DOI PubMed

28. Romero-Maroto J, Verdú-Verdú L, Gómez-Pérez L, Pérez-Tomás C, Pacheco-Bru JJ, López-López A. Lateral-based anterior vaginal wall flap in the treatment of female urethral stricture: efficacy and safety. Eur Urol 2018;73:123-8. DOI PubMed

29. Simonato A, Varca V, Esposito M, Carmignani G. Vaginal flap urethroplasty for wide female stricture disease. J Urol 2010;184:13815. DOI PubMed

30. Kowalik C, Stoffel JT, Zinman L, Vanni AJ, Buckley JC. Intermediate outcomes after female urethral reconstruction: graft vs flap. Urology 2014;83:1181-5. DOI PubMed

31. Hajebrahimi S, Maroufi H, Mostafaei H, Salehi-Pourmehr H. Reconstruction of the urethra with an anterior vaginal mucosal flap in female urethral stricture. Int Urogynecol J 2019;30:2055-60. DOI PubMed

32. Chakraborty JN, Chawla A, Vyas N. Surgical interventions in female urethral strictures: a comprehensive literature review. Int Urogynecol J 2021. DOI PubMed

33. Rehder P, Glodny B, Pichler R, Exeli L, Kerschbaumer A, Mitterberger MJ. Dorsal urethroplasty with labia minora skin graft for female urethral strictures. BJU Int 2010;106:1211-4. DOI PubMed

34. Gozzi C, Roosen A, Bastian PJ, Karl A, Stief C, Tritschler S. Volar onlay urethroplasty for reconstruction of female urethra in recurrent stricture disease. BJU Int 2011;107:1964-6. DOI PubMed

35. Petrou SP, Rogers AE, Parker AS, Green KM, McRoberts JW. Dorsal vaginal graft urethroplasty for female urethral stricture disease. BJU Int 2012;110:E1090-5. DOI PubMed

36. Singh M, Kapoor R, Kapoor D, Kapoor R, Srivastav A, Chipde S. Dorsal onlay vaginal graft urethroplasty for female urethral stricture. Indian J Urol 2013;29:124-8. DOI PubMed PMC

37. Sharma GK, Pandey A, Bansal H, et al. Dorsal onlay lingual mucosal graft urethroplasty for urethral strictures in women. BJU Int 2010;105:1309-12. DOI PubMed

38. Manasa T, Khattar N, Tripathi M, Varshney A, Goel H, Sood R. Dorsal onlay graft urethroplasty for female urethral stricture improves sexual function: short-term results of a prospective study using vaginal graft. Indian J Urol 2019;35:267-72. DOI PubMed PMC

39. Goel A, Paul S, Dalela D, Sankhwar P, Sankhwar SN, Singh V. Dorsal onlay buccal mucosal graft urethroplasty in female urethral stricture disease: a single-center experience. Int Urogynecol J 2014;25:525-30. DOI PubMed

40. Powell CR, Daniels D. Dorsal onlay buccal urethroplasty in the female is associated with high quality of life using validated lower urinary tract symptom instruments. Urology Practice 2017;4:48-53. DOI

41. Khawaja AR, Dar YA, Bashir F, Wani PM, Bhat AH, Wani MS. Outcome of dorsal buccal graft urethroplasty in female urethral stricture disease (FUSD); our institutional experience. Int Urogynecol J 2021. DOI PubMed

42. Nayak P, Mandal S, Das M. Ventral-inlay buccal mucosal graft urethroplasty for female urethral stricture. Indian J Urol 2019;35:2737. DOI PubMed PMC

43. Coguplugil AE, Ebiloglu T, Sarikaya S, Yilmaz S, Topuz B, Gurdal M. Ventral onlay buccal mucosa graft urethroplasty for female urethral stricture. Int J Urol 2021;28:538-43. DOI PubMed

44. Hampson LA, Myers JB, Vanni AJ, et al. Dorsal buccal graft urethroplasty in female urethral stricture disease: a multi-center experience. Transl Androl Urol 2019;8:S6-S12. DOI PubMed PMC

45. Gomez RG, Pfeifer J. Update on female urethral reconstruction. Curr Opin Urol 2021;31:486-92. DOI PubMed

46. Gomez RG, Segura FJ, Saavedra A, Campos RA. Female urethral reconstruction: dorsal buccal mucosa graft onlay. World J Urol 2020;38:3047-54. DOI PubMed

47. Versteegden LRM, de Jonge PKJD, IntHout J, et al. Tissue engineering of the urethra: a systematic review and meta-analysis of preclinical and clinical studies. Eur Urol 2017;72:594-606. DOI PubMed

48. Virasoro R, DeLong JM, Mann RA, et al. A drug-coated balloon treatment for urethral stricture disease: interim results from the ROBUST I study. Can Urol Assoc J 2020;14:187-91. DOI PubMed PMC 